\title{
A set of grounding-zone wedges in Vestfjorden, North Norway
}

\author{
J. A. DOWDESWELL ${ }^{1} *$ \& D. OTTESEN ${ }^{2}$ \\ ${ }^{1}$ Scott Polar Research Institute, University of Cambridge, Cambridge CB2 1ER, UK \\ ${ }^{2}$ Geological Survey of Norway, Postboks 6315 Sluppen, 7491 Trondheim, Norway
}

*Corresponding author (e-mail: jd16@cam.ac.uk)

At the Last Glacial Maximum (LGM), a $400 \mathrm{~km}$-long ice stream drained an interior drainage basin of the Scandinavian Ice Sheet of about $150,000 \mathrm{~km}^{2}$ through Vestfjorden and the adjacent crossshelf trough of Traenadjupet further downstream (Fig. 1) (Ottesen et al. 2005a). Evidence for past ice-stream activity comes from a variety of submarine sedimentary landforms that are streamlined in the direction of past ice flow (Ottesen et al. 2005b). Superimposed on these streamlined landforms are several wedgelike sedimentary features orientated transverse-to-flow. These submarine landforms suggest that deglacial retreat was punctuated by still-stands that produced substantial depocentres known as grounding-zone wedges (GZW) (e.g. Anderson 1999; Dowdeswell et al. 2008; Dowdeswell \& Fugelli 2012; Batchelor \& Dowdeswell 2015).

\section{Description}

In Vestfjorden, two large ridges and several smaller ones are located across the axis of the $70 \mathrm{~km}$-wide fjord. The largest ridge, sometimes referred to as the Tennholmen Ridge (Ottesen et al. 2005a), is about $80 \mathrm{~m}$ high and occurs at water depths of between approximately 200 and $300 \mathrm{~m}$ (Fig. 1a, b). It stretches about 60 $\mathrm{km}$ across the fjord and thins inshore along its $20 \mathrm{~km}$ length. The second large ridge is found in 220 to $260 \mathrm{~m}$ of water depth some $40 \mathrm{~km}$ further up Vestfjorden and is about $5 \mathrm{~km}$ in long-axis length and $30 \mathrm{~km}$ in cross-fjord width (Fig. 1a, c). The ridges are asymmetrical in along-fjord direction, with a relatively steeper seaward face and a longer but lower-gradient landward portion (Fig. 1a, d).

Seismic-reflection profiles show that the ridges have a transparent to chaotic appearance (Fig. 1e), suggesting that the upper and lower units are likely to be composed of unsorted till, with the upper unit about $80 \mathrm{~m}$ thick at maximum (Fig. 1d). By comparision with better dated fjords further north in Norway, it is inferred that the two large ridges date from the period of ice-sheet deglaciation from the LGM between about 15,000 and 12,500 radiocarbon years BP (Ottesen et al. 2005a; Laberg et al. 2009).

By contrast with the large transverse-to-flow ridges, several sets of small and highly elongate streamlined sedimentary ridges, just a few metres high and spaced about 200 to $500 \mathrm{~m}$ apart, are located parallel to the long axis of Vestfjorden (Fig. 1a-c). Importantly, some of these small streamlined features are clearly overridden by the sediments making up the two large ridges (Fig. $1 b$ ), whereas other sets are superimposed upon the surface of the ridges (Fig. 1a). This suggests that the process responsible for their formation was active both before, after, and perhaps during, the formation of the two large ridges.

Finally, the Tennholmen Ridge in particular, and the streamlined linear features on its surface, have a further landform type superimposed upon them in the form of a chaotic pattern of curvilinear depressions of a few metres in depth (Fig. 1a, b).

\section{Interpretation}

The two large asymmetrical sedimentary ridges, with steeper seaward or ice-distal faces and lower-gradient ice-proximal tails (Fig. 1a, d), are interpreted as GZWs formed during still-stands in ice-stream retreat during regional deglaciation. Both their asymmetrical form and their absolute dimensions, at tens of metres high, 5 to $20 \mathrm{~km}$ long and stretching tens of kilometres across the fjord, plot firmly within the envelope of dimensions for almost 150 mapped GZWs in Arctic and Antarctic fjords and cross-shelf troughs (Dowdeswell \& Fugelli 2012; Batchelor \& Dowdeswell 2015). The volume of the GZWs, and the likely rates of sediment delivery to ice-stream grounding zones (Alley et al. 2007), suggest that such landforms may have taken decades to a century or two to form. It is likely that the upper till unit recorded in seismic profiles represents sediment deposited during deglacial still-stands to form the GZWs, whereas that lower unit, beneath a single continuous reflection (Fig. 1c, d), relates to subglacially deposited sediments from the LGM.

The small and highly elongate streamlined linear landforms both underlying and superimposed upon the GZWs are interpreted as mega-scale glacial lineations (MSGLs). MSGLs typically form in deforming subglacial sediments beneath active ice streams (Clark 1993). Their presence therefore indicates that the GZWs were deposited in association with active ice, which would have been necessary to deliver sediments to the grounding-zone enabling depocentre buildup (Alley et al. 2007).

In addition, the presence of both MSGLs and GZWs suggests that deglaciation of Vestfjorden was episodic, with periods of still-stands in ice-margin position and GZW deposition punctuating more rapid retreat (Dowdeswell et al. 2008). Finally, the presence of chaotic depressions on the GZW crests at modern water depths of about $200 \mathrm{~m}$, which are interpreted as icebergkeel ploughmarks, implies that relatively large icebergs were produced as ice continued to retreat up Vestfjorden as deglaciation continued.

\section{References}

ALLEY, R.B., ANANDAKRISHNAN, S., DUPONT, T.K., PARIZEK, B.R. \& POLLARD D. 2007. Effect of sedimentation on ice-sheet grounding-line stability. Science, 315, 1838-1841.

ANDERSON, J.B. 1999. Antarctic Marine Geology. CUP, 289 pp.

BATCHELOR, C. L. \& DOWDESWELL, J. A. 2015. Ice-sheet grounding-zone wedges (GZWs) on high-latitude continental margins. Marine Geology, 363, 65-92.

CLARK, C. D. 1993. Mega-scale glacial lineations and crosscutting ice-flow landforms. Earth Surface Processes and Landforms, 18, 1-19.

DOWDESWELL, J. A. \& FUGELLI, E. M. G. 2012. The seismic architecture and geometry of grounding-zone wedges formed at the marine margins of past ice sheets. Bulletin of the Geological Society of America, 124, 1750-1761.

DOWDESWELL, J. A., OTTESEN, D., EVANS, J., Ó COFAIGH, C. \& ANDERSON, J. B. 2008. Submarine glacial landforms and rates of ice-stream collapse. Geology, 36, 819822.

LABERG, J.S., EILERTSEN, R.S. \& VORREN, T.O. 2009. The paleo-ice stream in Vestfjorden, north Norway, over the last 35 k.y.: Glacial erosion and sediment yield. Geological Society of America Bulletin, 121, 434-447.

OTTESEN, D., RISE, L., KNIES, J, OLSEN, L. \& HENRIKSEN S. 2005a. The Vestfjorden-Traenadjupet palaeo-ice stream drainage system, mid-Norwegian continental shelf. Marine Geology, 218, 175-189.

OTTESEN, D., DOWDESWELL, J. A. \& RISE, L. 2005b. Submarine landforms and the reconstruction of fast-flowing ice streams within a large Quaternary ice sheet: the $2500-\mathrm{km}-$ long Norwegian-Svalbard margin $\left(57^{\circ}-80^{\circ} \mathrm{N}\right)$. Geological Society of America Bulletin 117, 1033-1050. 

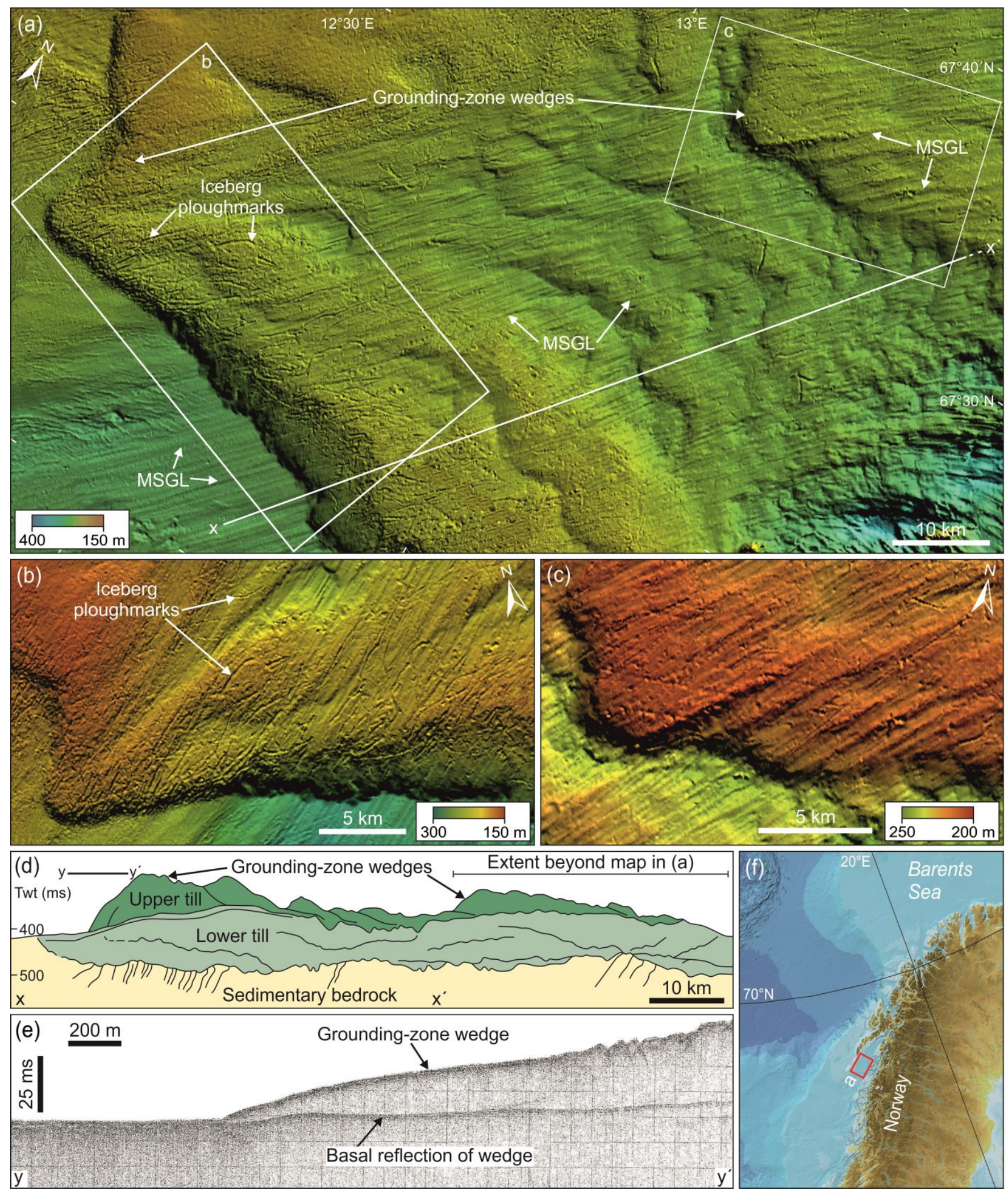

Fig. 1. Grounding-zone wedges in Vestfjorden, North Norwegian margin. (a) Shaded-relief swath-bathymetric image of a 5,500 $\mathrm{km}^{2}$ area of Vestfjorden showing two large GZWs which both override MSGLs and have further MSGLs on their surfaces. The shallowest parts of the GZWs have been affected by the ploughing action of iceberg keels. Acquisition system Kongsberg EM100. Frequency $97 \mathrm{kHz}$. Grid-cell size $50 \mathrm{~m}$. (b) and (c) Enlarged images of the icedistal sections of two GZWs, also showing MSGLs and iceberg ploughmarks. (d) Interpreted reflection-seismic profile along the axis of Vestfjorden showing upper and lower units, interpreted as till, and the asymmetrical long-profiles of the GZWs, located in (a). VE x 80. (e) Seismic-reflection profile through the ice-distal part of the westward GZW imaged in (a). VE x 10. This profile is located within the interpreted and much longer profile shown in (d). (f) Location of study area (red box; map from IBCAO v. 3.0). 